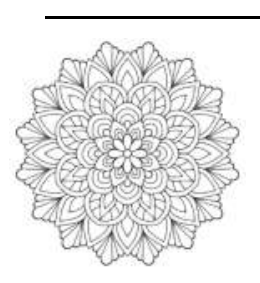

AL HIKMAH: INDONESIAN JOURNAL OF EARLY CHILDHOOD ISLAMIC

EDUCATION

ISSN (P): 2550-2200, ISSN (E): 2550-1100,

VOL. 5 (2), 2021, PP. 112 - 121

http://journal.iaialhikmahtuban.ac.id/index.php/ijecie

\title{
HUBUNGAN STATUS GIZI DENGAN PERKEMBANGAN KOGNITIF ANAK USIA 5-6 TAHUN
}

\author{
Linda. D.P ${ }^{1}$, Ridha. ${ }^{2}{ }^{2}$, Muzakki ${ }^{3}$ \\ ${ }^{123}$ Pendidikan Islam Anak Usia Dini, Fakultas Tarbiyah dan Ilmu Keguruan, IAIN Palangka Raya \\ pitriani.linda@gmail.com
}

\begin{abstract}
Hubungan status gizi dengan perkembangan kognitif pada anak dan balita, termasuk dalam golongan masyarakat kelompok rentan gizi. Kurangnya gizi pada anak dan balita dapat menyebabkan lemah, konsentrasi menurun dan perkembangan anak melambat. Tujuan penelitian ini yaitu untuk mengetahui hubungan status gizi dengan perkembangan kognitif anak usia 5-6 tahun di RA Hidayatul Insan Palangka Raya. Metode penelitian yang digunakan adalah penelitian kuantitatif dengan pendekatan korelasional, metode yang digunakan survei analitik. Sampel dalam penelitian ini sebanyak 25 peserta didik dengan metode sampling yaitu menggunakan sampling total, dimana semua populasi dijadikan sampel. Teknik pengumpulan data penelitian menggunakan observasi, angket dan wawancara. Analisis data menggunakan uji korelasi product moment. Hasil penelitian menunjukkan bahwa penghitungan uji korelasi product moment diketahui hubungan indeks masa tubuh dengan perkembangan kognitif anak dengan nilai signifikan lebih kecil dari nilai alpha atau $0,009<0,05$. Pada hubungan lingkar lengan atas dengan perkembangan anak dengan nilai signifikan lebih kecil dari nilai alpha atau 0,024<0,05 dengan demikian Ha diterima, nilai correlations sebesar $-0,512$ dan $-0,449$. Kesimpulan bahwa adanya hubungan yang sangat lemah antara status gizi dengan perkembangan kognitif anak usia 5-6 tahun di RA Hidayatul Insan Palangka Raya.

Kata kunci : status gizi, perkembangan kognitif, anak usia dini
\end{abstract}

Abstrak

\section{Abstract}

The relationship between nutritional status and cognitive development in children and toddlers, including those in the nutritionally vulnerable group. Lack of nutrition in children and toddlers can cause weakness, decreased concentration and slowed child development. The purpose of this study are to determine the relationship between nutritional status and cognitive development of children aged 5-6 years in RA Hidayatul Insan Palangka Raya. The research method used was quantitative research with a correlational approach, the method used was an analytic survey. The sample in this study were 25 students with a sampling method, namely used total sampling, where all populations were sampled. Research data collection techniques used observation, questionnaires and interviews. Data analysis used product moment correlation test. The results showed that the calculation of the product moment correlation test found that the relationship between body mass index and children's cognitive development was significantly smaller than the alpha value or $0.009<0.05$. In the relationship between upper arm circumference and child development with a significant value smaller than the alpha value or $0.024<0.05$, thus Ha was accepted, the correlations of -0.512 and 0.449 . The conclusion was that there was a very weak relationship between nutritional status and cognitive development of children aged 5-6 years in RA Hidayatul Insan Palangka Raya.

Keywords: nutritional status, cognitive development, early childhood 


\section{PENDAHULUAN}

Pada umumnya perkembangan kognitif sangat berhubungan dengan masa perkembangan motorik. Perkembangan kognitif menjelaskan bagaimana pikiran anak berkembang dan berfungsi, sehingga dapat berpikir. Perkembangan kognitif adalah proses dimana individu dapat meningkatkan kemampuan dalam menggunakan pengetahuannya. Kemampuan kognitif adalah kemampuan anak untuk berpikir lebih kompleks serta melakukan penalaran dan pemecahan masalah, berkembangnya kemampuan kognitif ini akan mempermudah anak menguasai pengetahuan umum yang lebih luas, sehingga anak dapat berguna dalam kehidupan bermasyarakat. Akan tetapi dalam perkembangannya tidak semua anak dapat berkembang sesuai tahapannya, sehingga perlu dilakukan analisa.

Asupan makanan bergizi bagi manusia sangat penting, asupan gizi yang tidak baik dapat menimbulkan berbagai permasalahan. Baik itu permasalahan kesehatan, daya tahan tubuh, atau perkembangan dan pertumbuhan. Pemenuhan asupan gizi yang seimbang tidak hanya dapat mengoptimalkan tumbuh kembang anak saja tetapi dapat memberikan dampak baik bagi tubuh (Thamaria, 2017: 5). Untuk mengetahui fisik dan kesehatan anak dapat menggunakan penilaian status gizi, penilaian indeks masa tubuh anak serta lingkar lengan atas anak dapat digunakan untuk penentuan status gizi anak.

Pemenuhan gizi seimbang sangat penting bagi anak, hasil penelitian (Alestari, 2019: 401) bahwa terdapat hubungan status gizi dengan perkembangan kognitif pada anak, karena gizi kurang dapat membuat anak lemah, kurang fokus, perkembangan anak mengalami keterlambatan, sehingga mengakibatkan perkembangan berfikir anak menurun. Pembahasan tersebut peneliti tertarik untuk mengetahui bagaimana hubungan antara status gizi dengan perkembangan kognitif anak usia 5-6 tahun di RA Hidayatul Insan Palangka Raya.

Ditinjau dari hubungan status gizi dengan perkembangan berfikir pada anak, balita termasuk dalam golongan masyarakat kelompok rentan gizi, karena pada masa ini merupakan masa peralihan dari saat disapih (berhenti dari susuan ibu) dan mulai diberikan makanan. Pada masa ini tidak sedikit orangtua atau pengasuh anak keliru dalam memberikan asupan gizi untuk anak. Pada kebanyakan, asupan gizi untuk anak mengikuti pola kebiasaan pemberian makanan untuk orang dewasa atau bukan untuk anak.

Status gizi adalah keadaan tubuh yang diakibatkan oleh keseimbangan antara asupan zat gizi yang diperoleh dari makanan dengan kebutuhan zat gizi yang diperlukan untuk metabolisme tubuh. Status gizi dapat dikatakan suatu kondisi dari kekurangan maupun kelebihan zat gizi pada tubuh, namun lebih sering dikenal dengan kekurangan gizi. Gizi kurang adalah permasalahan yang ada pada kesehatan dengan melihat dari meningkatnya resiko 
mortalitas dan morbiditas. Menurut Prameswari (2017: 3) yang dimaksud status gizi adalah keadaan tubuh yang merupakan hasil dari keseimbangan antara gizi yang masuk ke dalam tubuh dan penggunaannya.

Perkembangan kognitif pada anak usia dini adalah sebuah perkembangan kecerdasan dan daya berpikir pada pengetahuan anak. Selain itu, intelegensi sebagai kemampuan untuk memecahkan masalah atau menciptakan karya yang dihargai dalam suatu kebudayaan atau lebih serta pengukuran perkembangan kognitif menggunakan tes disesuaikan dengan karakteristik usia anak yang berkisar 5-6 tahun. Menurut Khadijah (2016: 34) Perkembangan kognitif anak usia dini adalah kemampuan cara berpikir anak dalam memahami lingkungan sekitar sehingga pengetahuan anak bertambah.

Karakteristik perkembangan kognitif menurut Jean Peaget yang di digunakan pada penelitian ini ada dua tahap, yaitu tahap sensori motor dan tahap pra operasional. Karena pada tahapan ini merupakan tahap pertama perkembangan anak yang sangat dipengaruhi oleh gizi yang di konsumsi oleh anak. Karakteristik perkembangan kognitif anak usia 5-6 tahun menurut Permendikbud (2014: 24-25) di bagi menjadi tiga indikator, diantaranya belajar dan pemecahan masalah, berpikir simbolik, dan berpikir logis.

\section{METODE}

Penelitiani ini menggunakan penelitian kuantitatif, dengan pendekatan korelasional untuk melihat hubungan antara dua variabel. Penelitian ini menggunakan metode survei analitik. Menurut Masturoh (2018: 129) survei analitik merupakan survei yang digunakan untuk mengetahui bagaimana dan mengapa fenomena terjadi.

Populasi dalam penelitian ini adalah semua peserta didik kelas B di RA Hidayatul Insan Palangka Raya ajaran 2020/2021. Sampel penelitian ini yaitu semua populasi penelitian di jadikan sampel yang berjumlah 25 peserta didik yang ditentukan dengan menggunakan teknik sampling total. Teknik pengumpulan data penelitian menggunakan obsertvasi, angket dan wawancara.

Instrumen penelitian menggunakan angket yang dipergunakan untuk mengetahui perkembangan kognitif anak dan daftar pengukuran status gizi. teknik analisis data peneliti menggunakan analisi korelasi, sebelum melaksanakan analisi korelasi terlebih dahulu melaksanakan uji normalitas data serta uji hipotesis. 


\section{HASIL DAN PEMBAHASAN}

Hasil penelitian diketahui melalui pengujian hipotesis menggunakan uji korelasi product moment, sebelum tahap tersebut dilakukan terlebih dahulu melakukan uji normalitas data. Penelitian dilakukan sebanyak 6 kali, 4 kali pertemuan saat pengukuran status gizi dan 2 kali pertemuan saat pengumpulan data perkembangan kognitif. Berikut merupakan hasil penelitian pada pengukuran status gizi dan perkembangan kognitif.

Pengumpulan data status gizi peneliti melakukan penggalian data dengan melakukan pengukuran Indeks Massa Tubuh (IMT) dan Lingkar Lengan Atas (LILA) peserta didik. Berikut merupakan uraian hasil pengumpulan data yang dilakukan oleh peneliti.

Tabel 1. Indeks Massa Tubuh Anak

\begin{tabular}{cccccc}
\hline No & Kategori & Jumlah & Skor & Presentase & Kualifikasi \\
\hline $\mathbf{1}$ & Kurus & 4 & 1 & $16 \%$ & Gizi buruk \\
\cline { 3 - 6 } & & 5 & 2 & $20 \%$ & Gizi kurang \\
\hline $\mathbf{2}$ & Normal & 12 & 3 & $48 \%$ & Gizi baik \\
\hline $\mathbf{3}$ & Gemuk & 4 & 4 & $16 \%$ & Gizi lebih \\
\cline { 3 - 6 } & & 0 & 5 & $0 \%$ & Obesitas \\
\hline & & & & & Gata-rata \\
\end{tabular}

Dari data tersebut diketahui bahwa ada 4 peserta didik yang berada pada kualifikasi gizi buruk, 5 berkualifikasi gizi kurang, 12 berkualifikasi gizi baik, dan 4 berkualifikasi gizi lebih. Diketahui dari data tersebut maka peserta didik di RA Hidayatul Insan rata-rata berada pada kualifikasi gizi baik sebesar $48 \%$.

Tabel 2. Lingkar Lengan Atas anak

\begin{tabular}{clcccc}
\hline No & Kategori & Jumlah & Skor & Presentase & Kualifikasi \\
\hline $\mathbf{1}$ & Kurus & 4 & 1 & $16 \%$ & Gizi buruk \\
\cline { 3 - 6 } & & 2 & 2 & $8 \%$ & Gizi kurang \\
\hline $\mathbf{2}$ & Normal & 13 & 3 & $52 \%$ & Gizi baik \\
\hline $\mathbf{3}$ & Gemuk & 2 & 4 & $8 \%$ & Gizi lebih \\
\cline { 2 - 6 } & & 4 & 5 & $16 \%$ & Obesitas
\end{tabular}

\section{Rata-rata}

Gizi baik

Sumber : Hasil Penelitian 
Linda. D.P, Ridha. N, Muzakki (Hubungan Status Gizi)

Dari data tersebut diketahui bahwa sebanyak 4 peserta didik yang berada pada kualifikasi gizi buruk, 2 berkualifikasi gizi kurang, 13 berkualifikasi gizi baik, 2 berkualifikasi gizi lebih, dan 4 berkualifikasi obesitas. Diketahui dari data tersebut peserta didik di RA Hidayatul Insan rata-rata berada pada kualifikasi gizi baik sebesar 52\%, akan tetapi masih ada sebagian peserta didik yang memiliki kualifikasi obesitas, gizi lebih, gizi kurang, dan juga gizi buruk.

Berikut merupakan hasil rekapitulasi perkembangan kognitif anak usia 5-6 tahun di RA Hidayatul Insan Palangka Raya yang diperoleh peneliti melalui angket.

Tabel 3. Rekapitulasi Data Perkembangan Kognitif Anak Usia 5-6 Tahun Di RA Hidyatul Insan Palangka Raya

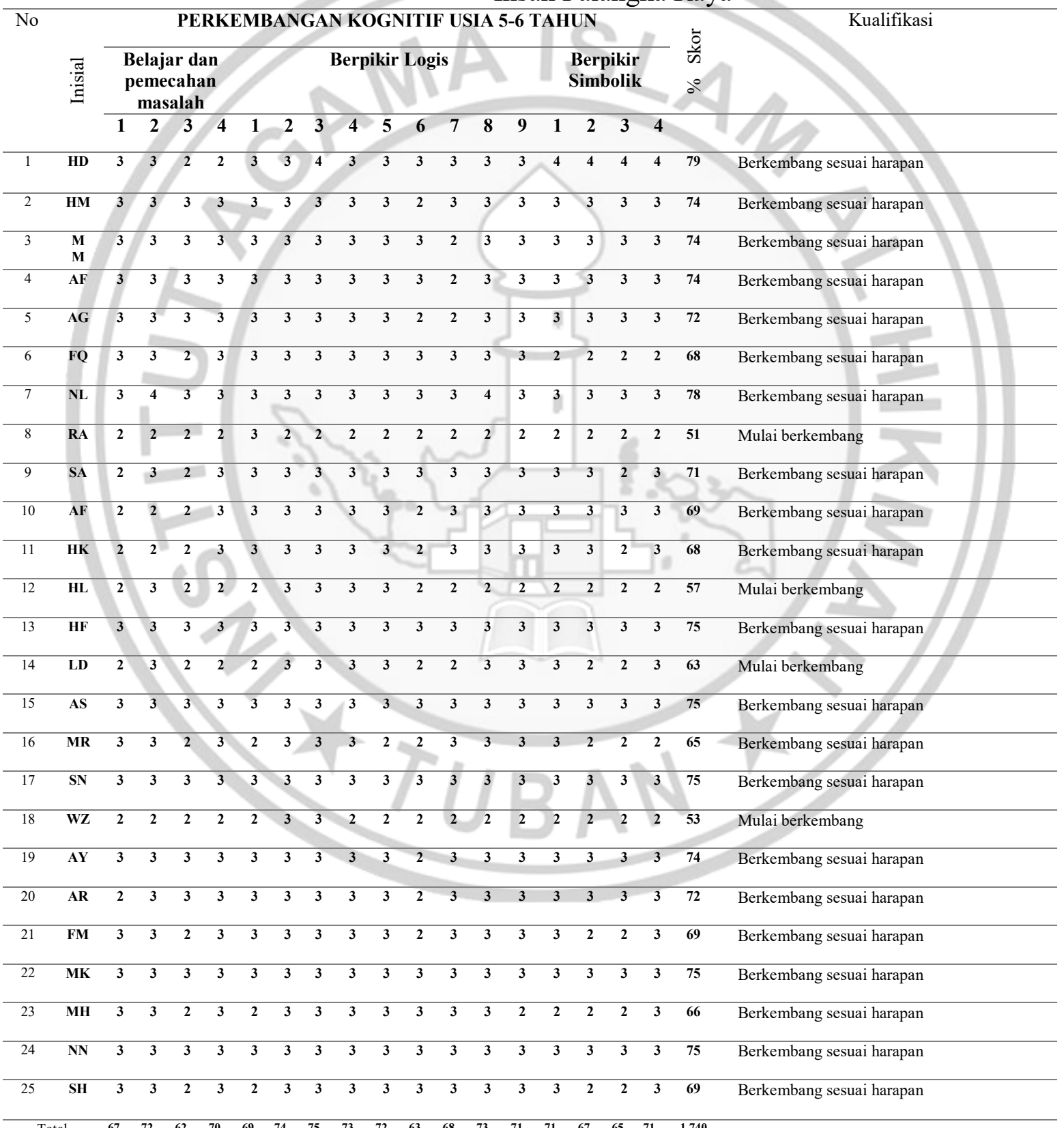


Berdasarkan data pada tabel 3 di atas bahwa perkembangan kognitif memiliki tiga indikator yang dapat di uraikan sebagai berikut:

1. Belajar dan pemecahan masalah

Bersumber dari hasil wawancara dan melihat hasil belajar peserta didik, diketahui bahwa rata-rata skor yang didapatkan pada perkembangan kognitif dalam hal belajar dan pemecahan masalah sederhana sebanyak 8 peserta didik mulai berkembang atau $32 \%$ dan sebanyak 17 peserta didik berkembang sesuai harapan atau sebesar 68\%.

2. Berpikir logis

Menurut data yang didapatkan peneliti dengan melakukan wawancara dan melihat hasil belajar peserta didik, peneliti memperoleh data bahwa rata-rata skor dalam hal berpikir logis sebanyak 3 peserta didik mulai berkembang atau $12 \%$ dan sebanyak 22 peserta didik sudah berkembang sesuai harapan atau sebesar $88 \%$.

3. Berpikir simbolik

Berdasarkah hasil yang diperoleh peneliti dengan melakukan wawancara dan melihat hasil belajar peserta didik, peneliti memperoleh data bahwa rata-rata skor dalam hal berpikir simbolik sebanyak 9 peserta didik mulai berkembang atau 36\%, sebanyak 15 peserta didik berkembang sesuai harapan atau sebesar $60 \%$, dan sebanyak 1 peserta didik berkembang sangat baik atau sebesar $4 \%$.

Hubungan indeks masa tubuh dengan perkembangan kognitif anak di RA Hidayatul Insan Palangka Raya dengan melakukan pengujian uji product moment didapatkan hasil bahwa koefisien korelasi sebesar -0,512 dengan signifikansi 0,009. Dengan membandingkan taraf signifikan dengan alpha diketahui nilai signifikansi lebih kecil dari 0,05 atau 0,009<0,05, maka Ha diterima yang artinya terdapat hubungan antara indeks masa tubuh dengan perkembangan kognitif anak usia 5-6 tahun di RA Hidayatul Insan Palangka Raya. Berikut merupakan penjelasan tentang hubungan indeks massa tubuh dengan perkembangan kognitif dalam belajar dan pemecahan masalah, berpikir simbolik dan berpikir logis untuk anak usia 5-6 tahun.

1. Indeks masa tubuh dengan belajar dan pemecahan masalah

Melihat data indeks massa tubuh dengan perkembangan kognitif diketahui bahwa tidak semua peserta didik yang memiliki gizi buruk dan kurang dalam perkembangan kognitifnya bermasalah. Dimana hasil penelitian menunjukkan peserta didik yang termasuk kualifikasi gizi buruk memiliki perkembangan kognitif dalam hal belajar dan pemecahan masalah berkembang sesuai harapan, ada juga peserta didik yang memiliki gizi kurang tetapi perkembangan kognitif dalam hal belajar dan pemecahan masalah berkembang sesuai 
harapan, dan peserta didik yang berkualifikasi gizi baik memiliki perkembangan kognitif dalam hal belajar pemecahan masalah masuk kualifikasi mulai berkembang. Hal ini terjadi karena perkembangan kognitif anak dipengaruhi oleh faktor genetik dan lingkungan (Khadijah, 2016: 41-47). Seperti halnya pendapat (Elnovriza, 2012: 80) bahwa kecerdasan seorang anak tidak hanya dipengaruhi oleh satu faktor saja tetapi dua faktor, yaitu faktor genetik dan faktor lingkungan. Kemampuan berpikir dapat berkembang apabila anak diberikan rangsangan sejak usia dini. Rangsangan anak didapatkan sejak anak dalam kandungan, lingkungan keluarga dan lingkungan masyarakat.

2. Indeks masa tubuh dengan berpikir logis

Peserta didik yang termasuk kualifikasi gizi kurang dan gizi baik dalam hal berpikir logis rata-rata berkembang sesuai harapan, ada peserta didik yang kualifikasi gizi lebih dalam perkembangan kognitif berpikir logis mulai berkembang, dan ada juga kualifikasi gizi buruk dalam perkembangan kognitif mulai berkembang. Hal ini terjadi karena perkembangan kognitif anak dipengaruhi oleh faktor genetik dan lingkungan (Khadijah, 2016: 41-47). Seperti halnya pendapat (Elnovriza, 2012: 80) bahwa kecerdasan seorang anak tidak hanya dipengaruhi oleh satu faktor saja tetapi dua faktor, yaitu faktor genetik dan faktor lingkungan. Kemampuan berpikir dapat berkembang apabila anak diberikan rangsangan sejak usia dini. Rangsangan anak didapatkan sejak anak dalam kandungan, lingkungan keluarga dan lingkungan masyarakat.

3. Indeks masa tubuh dengan berpikir simbolik

Tidak semua peserta didik yang termasuk kualifikasi gizi kurang, gizi buruk dan gizi lebih dalam hal berpikir logis memiliki masalah. Dari hasil penelitian menunjukkan bahwa ada peserta didik yang termasuk kualifikasi gizi lebih tetapi dalam perkembangan kognitif berpikir simbolik berkembang sesuai harapan dan ada juga yang mulai berkembang. Peserta didik yang termasuk kualifikasi gizi buruk tetapi dalam perkembangan kognitif berpikir simbolik berkembang sesuai harapan dan ada juga yang mulai berkembang. Keadaan ini terjadi karena perkembangan kognitif anak dipengaruhi oleh faktor genetik dan lingkungan (Khadijah, 2016: 41-47). Seperti halnya pendapat (Elnovriza, 2012: 80) bahwa kecerdasan seorang anak tidak hanya dipengaruhi oleh satu faktor saja tetapi dua faktor, yaitu faktor genetik dan faktor lingkungan. Kemampuan berpikir anak juga dapat berkembang optimal apabila anak mendapatkan rangsangan sejak usia dini. Rangsangan anak diberikan sejak anak dalam kandungan, lingkungan keluarga dan lingkungan masyarakat. 
Hubungan lingkar lengan atas dengan perkembangan kognitif anak di RA Hidayatul Insan Palangka Raya, didapatkan hasil dari pengujian korelasi bahwa koefisien korelasi sebesar $-0,449$ dengan nilai signifikansi 0,024 . Dengan membandingkan taraf signifikan dengan alpha diketahui bahwa nilai signifikansi lebih kecil dari 0,05 atau 0,024<0,05, maka Ha diterima yang artinya terdapat hubungan yang signifikan antara lingkar lengan atas dengan perkembangan kognitif anak usia 5-6 tahun di RA Hidayatul Insan Palangka Raya. Berikut merupakan penjelasan tentang hubungan lingkar lengan atas dengan perkembangan kognitif dalam belajar dan pemecahan masalah, berpikir simbolik dan berpikir logis untuk anak usia 5-6 tahun.

1. Lingkar lengan atas dengan belajar dan pemecahan masalah

Hubungan lingkar lengan atas dengan perkembangan kognitif belajar dan pemecahan masalah diketahui bahwa hasil penelitian menunjukkan tidak semua peserta didik yang termasuk dalam kualifikasi gizi baik dalam perkembangan kognitif belajar dan pemecahan masalah selalu baik. Dimana peserta didik yang termasuk kualifikasi gizi baik dalam perkembangan kognitif belajar dan pemecahan masalah ada yang mulai berkembang, tetapi ada juga yang berkembang sesuai harapan. Peserta didik berkualifikasi obesitas dalam perkembangan kognitif belajar dan pemecahan masalah rata-rata mulai berkembang. Peserta didik yang berkualifikasi gizi buruk diketahui dalam perkembangan kognitif belajar dan pemecahan masalah ada yang mulai berkembang dan juga berkembang sesuai harapan. Keadaan ini terjadi karena perkembangan kognitif anak dipengaruhi oleh faktor genetik dan lingkungan (Khadijah, 2016: 41-47). Seperti halnya pendapat (Elnovriza, 2012: 80) bahwa kecerdasan seorang anak tidak hanya dipengaruhi oleh satu faktor saja tetapi dua faktor, yaitu faktor genetik dan faktor lingkungan. Kemampuan berpikir anak juga dapat berkembang optimal apabila anak mendapatkan rangsangan sejak usia dini. Rangsangan anak diberikan sejak anak dalam kandungan, lingkungan keluarga dan lingkungan masyarakat.

2. Lingkar lengan atas dengan berpikir logis

Hubungan lingkar lengan atas dengan perkembangan kognitif berpikir logis, peserta didik yang termasuk kualifikasi gigi kurang, gizi baik dan gizi lebih dalam hal berpikir logis rata-rata berkembang sesuai harapan, ada peserta didik yang berkualifikasi gizi buruk dalam perkembangan kognitif berpikir logis mulai berkembang, dan ada juga kualifikasi obesitas dalam perkembangan kognitif mulai berkembang. Keadaan ini terjadi karena perkembangan kognitif anak dipengaruhi oleh faktor genetik dan lingkungan (Khadijah, 2016: 41-47). Seperti halnya pendapat (Elnovriza, 2012: 80) bahwa kecerdasan seorang anak tidak hanya 
dipengaruhi oleh satu faktor saja tetapi dua faktor, yaitu faktor genetik dan faktor lingkungan. Kemampuan berpikir anak juga dapat berkembang optimal apabila anak mendapatkan rangsangan sejak usia dini. Rangsangan anak diberikan sejak anak dalam kandungan, lingkungan keluarga dan lingkungan masyarakat.

3. Lingkar lengan atas dengan Berpikir simbolik

Hubungan lingkar lengan atas dengan perkembangan kognitif berpikir simbolik, diketahui bahwa tidak semua peserta didik yang termasuk kualifikasi gigi kurang, gizi buruk, gizi lebih dan obesitas dalam hal berpikir logis memiliki masalah. Dimana hasil penelitian menunjukkan bahwa ada peserta didik yang termasuk kualifikasi gizi lebih tetapi dalam perkembangan kognitif berpikir simbolik berkembang sesuai harapan dan ada juga yang mulai berkembang. Peserta didik ada yang termasuk kualifikasi gizi buruk tetapi dalam perkembangan kognitif berpikir simbolik Berkembang Sesuai Harapan (BSH) dan ada juga yang Mulai Berkembang (MB). dan ada juga peserta didik berkualifikasi obesitas tetapi dalam perkembangan kognitif berpikir simbolik Berkembang Sesuai Harapan (BSH) dan ada juga yang Mulai Berkembang (MB). Keadaan ini terjadi karena perkembangan kognitif anak dipengaruhi oleh faktor genetik dan lingkungan (Khadijah, 2016: 41-47). Seperti halnya pendapat (Elnovriza, 2012: 80) bahwa kecerdasan seorang anak tidak hanya dipengaruhi oleh satu faktor saja tetapi dua faktor, yaitu faktor genetik dan faktor lingkungan. Kemampuan berpikir anak juga dapat berkembang optimal apabila anak mendapatkan rangsangan sejak usia dini. Rangsangan anak diberikan sejak anak dalam kandungan, lingkungan keluarga dan lingkungan masyarakat.

\section{PENUTUP}

\section{Simpulan}

Berdasarkan penghitungan uji korelasi product moment Hubungan status gizi dengan perkembangan kognitif anak usia 5-6 tahun di RA Hidayatul Insan Palangka Raya dapat peneliti simpulkan bahwa terdapat hubungan. Hubungan indeks massa tubuh dengan perkembangan kognitif anak dengan nilai signifikan lebih kecil dari nilai alpha atau 0,009< 0,05 dengan taraf signifikan $5 \%=0,05$. Dan pada hubungan lingkar lengan atas dengan perkembangan anak dengan nilai signifikan lebih kecil dari nilai alpha atau 0,024<0,05. Hubungan indeks masa tubuh dengan perkembangan kognitif pada penelitian ini sangat lemah dilihat dari hasil penghitungan nilai $r$ hitung lebih kecil dari $r$ tabel atau $-0,512<0,396$. Dan lingkar lengan atas $r$ hitung lebih kecil dari $r$ tabel atau $-0,449<0,396$.

\section{Saran}

120 AL HIKMAH: INDONESIAN JOURNAL OF EARLY CHILDHOOD ISLAMIC EDUCATION $\mid$ VOL 5. No.2 Tahun 2021 
Kepada pihak sekolah khususnya guru, kepala sekolah dan staf yang berada di sekolah di harapkan dapat melakukan pengukuran kepada anak secara berkala. Orang tua peserta didik dapat lebih memperhatikan asupan gizi yang dikonsumsi baik saat anak masih dalam kandungan sampai usia pra sekolah agar kesehatan serta tumbuh kembang anak berkembang secara optimal. Penelitian yang akan datang diharapkan dapat melakukan dengan populasi dan sampel tidak hanya satu sekolah tetapi lebih dari yang dilakukan peneliti.

\section{DAFTAR PUSTAKA}

Alestari, dkk. (2019). Kaitan Status Gizi Dengan Perkembangan Kognitif Anak Usia 3-4 Tahun Di PAUD Mawar Kelurahan Tlogomas Malang, 4.

Elnovriza, D. dan R. Y. (2012). Hubungan Status Gizi Dan Keikutsertaan Dalam Layanan Tumbuh Kembang Terhadap Kemampuan. Jurnal Kesehatan Masyarakat, 6(2), 80-85.

Khadijah. (2016). Pengembangan Kognitif Anak Usia Dini. Medan: Perdana Publishing.

Masturoh, I. dan N. A. (2018). Metodelogi Penelitian Kesehatan. Acta Universitatis Agriculturae et Silviculturae Mendelianae Brunensis, 53(9), 1689-1699.

Permendikbud. (2014). Standar Nasional Pendidikan Anak Usia Dini. Peraturan Menteri Pendidikan Dan Kebudayaan Republik Indonesia, 13.

Prameswari, D. A. dan D. Y. dan D. M. (2017). Pengaruh Status Gizi Terhadap Perkembangan Motorik Kasar, 1-8. 